\title{
Mice as an Animal Model for the Study of Adipose Tissue and Obesity
}

\author{
Ratones como Modelo Animal para el Estudio del Tejido Adiposo y la Obesidad
}

\author{
Carlos Alberto Mandarim-de-Lacerda ${ }^{1}$; Mariano del Sol ${ }^{2}$; Bélgica Vásquez ${ }^{3}$ \& Marcia Barbosa Aguila ${ }^{1}$
}

\begin{abstract}
MANDARIM-DE-LACERDA, C. A.; DEL SOL, M.; VÁSQUEZ, B. \& AGUILA, B. M. Mice as an animal model for the study of adipose tissue and obesity. Int. J. Morphol., 39(6):1521-1528, 2021.

SUMMARY: The study of adipose tissue has gained increasing importance in the biomedical area due to its implications for health and obesity. Obesity is a situation of great concern mainly in the Western world due to its high prevalence and morbidity. Experimental studies on obesity often need a model where it is possible to carry out experiments, drug testing, and other therapeutic procedures, which are typically not possible in humans. Although several animals are used for obesity studies, rodents are by far the most used animals, and among rodents, mice are particularly indicated for this investigation. This mini review will introduce the challenging classification of obesity in rodents, paralleling human obesity, defining and classifying what an obese mouse is. The text will differentiate between white adipose tissue (WAT, aimed at endocrine secretion and lipogenesis) and brown adipose tissue (BAT, aimed at thermogenesis) and describe the browning process of white adipocytes in an adaptation to increase thermogenesis. The text will also describe the various types of body fat in mice with their differences and indications for investigation and teach how to recognize and dissect these fats. At the end of this introductory reading, the young researcher is expected to have acquired sufficient knowledge to start an experimental investigative project on obesity.
\end{abstract}

KEYWORDS: Obesity; White adipose tissue; Brown adipose tissue; Fat pads; Mice.

\section{INTRODUCTION}

Obesity occurs with a positive energy balance, i.e., excess caloric intake linked to a low caloric expenditure (Bluher, 2019). Overweight and obesity are identified as abnormal or excessive growth of fat that can harm health. Hormones produced in adipose tissue, intestine, liver, and other target organs, and appetite regulation and satiety controlled by the hypothalamus, are relevant in obesity (Spezani et al., 2020). Furthermore, parental obesity can affect the health and longevity of children (Armitage et al., 2008), with inflammation in the hypothalamus and hyperleptinemia, culminating in food hyperphagia in offspring (Ornellas et al., 2016).

World Health Organization counted more than 1.9 billion people overweight in 2016 (39\% of the world's adult population), whose were considered obese more than 650 million ( $13 \%$ of the world's adult population). Worldwide, the number of obese people has nearly tripled since 1975 (WHO, 2021).
White adipose tissue (WAT) is an endocrine organ that affects energy metabolism via lipolysis, lipogenesis, and energy storage by triacylglycerol (Fonseca-Alaniz et al., 2007). In addition, WAT secretes hormones, such as leptin and adiponectin, which act in different metabolic pathways of homeostasis. Animals "silenced" for the leptin gene, for example, develop obesity and associated comorbidities such as non-alcoholic fatty liver disease (Martins et al., 2021). Moreover, brown adipose tissue (BAT) shows an endocrine function more linked to thermogenesis (Villarroya et al., 2017). Table I summarizes the secretions of WAT and BAT.

In rodents, there are several models for studying obesity. The most used monogenic mutations in the leptin pathways (ob/ob mouse, db/db mouse. Zucker rat) and other monogenic models (Otsuka Long Evans Tokushima fat rat - OLETF). Also, polygenic models, diet-induced obesity (DIO), maternal overfeeding, and others.

\footnotetext{
${ }^{1}$ Laboratory of Morphometry, Metabolism, and Cardiovascular Diseases. Biomedical Center, Institute of Biology. The University of the State of Rio de Janeiro, Rio de Janeiro, Brazil.

${ }^{2}$ Doctoral Program in Morphological Sciences, Universidad de La Frontera, Temuco, Chile.

${ }^{3}$ Faculty of Health Sciences, Universidad de Tarapacá, Iquique, Chile.
} 
DIO animals mimic better the state of common obesity in humans and may be the best choice for testing future therapeutics. In addition, transgenic models may be used to explore the role of specific molecular targets and pathways in the physiology of food intake and their potential role in obesity (Lutz \& Woods, 2012). DIO C57BL/6 mice triggers standard features of human metabolic syndrome. After 16 weeks on a high-fat diet (60\% fat) (Aguila et al., 2021), mice showed more significant BW gain and visceral fat pads. Moreover, impairment of glucose clearance and insulin resistance are installed. The mice showed pancreas and liver masses increase with large pancreatic islet size and significantly intense alpha and beta-cell immunodensities (Fraulob et al., 2010).

\section{WAT and lipogenesis. BAT and thermogenesis}

The primary function of adipose tissue is to maintain energy balance, which involves the development of obesity. In addition, adipocytes are specialized in regulatory functions in homeostasis. Both types of adipose tissue, WAT and BAT, are described in mammals and exhibit distinct characteristics (Fig. 1) (Gesta et al., 2007).

WAT adipocytes are unilocular (reserve of a single macro droplet of fat), distributed throughout the body in greater quantity. However, BAT exists in smaller quantities, in specific places, whose adipocytes are multilocular with the fat reserve in microdroplets and abundant mitochondria in the cytoplasm (Langin, 2010).
The adipokines, the adipose tissue distribution, and the metabolism of carbohydrates are significantly influenced by the lipid content in the diet than by the absolute amount of lipids. In an experiment with a high-fat diet (60\% fat), different formulations were produced with different fat compositions, such as lard, olive oil, sunflower oil, and canola oil. As a result, leptin was more expressed, whereas adiponectin was less expressed with high-fat diets containing lard and olive oil. Also, the subcutaneous to visceral fat ratio was significantly lower with lard and olive oil than the other high-fat diets (Catta-Preta et al., 2012).

Batokines are adipokines secreted by BAT with autocrine and paracrine effects. Signaling molecules are released by adipocytes and target sympathetic nerve endings, vascular cells, and immune cells. In addition, BAT also has an endocrine function since batokines can actin other organs, such as the recognition of fibroblast growth factor 21 and myostatin, secreted by BAT, which targets the heart and skeletal muscle (Villarroya et al., 2019).

Unlike paraffin embedding and hematoxylin and eosin stain, which does not preserve the adipocyte content (extracted when sections are deparaffined), the oil red technique preserves the entire adipocyte and stains adipocyte cytoplasm. Fresh adipose tissue fragments should be embedded in Tissue-Tek OCT (Finetechnical Sakura, Tokyo, Japan) in aluminum molds, frozen quickly in liquid nitrogen, and stored at $-80{ }^{\circ} \mathrm{C}$ until microtomy. Frozen sections with

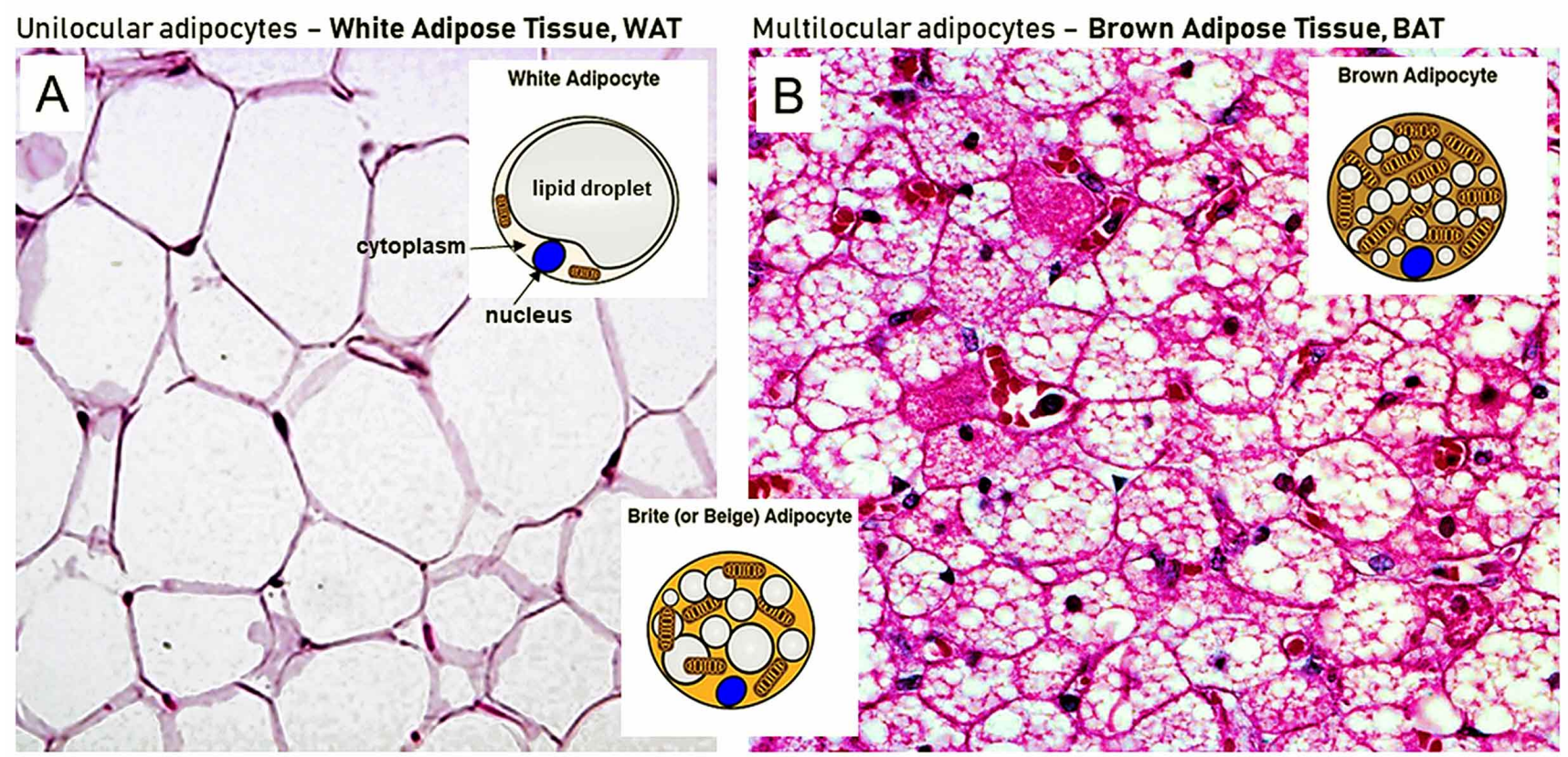

Fig. 1. The adipocytes. (A) White adipose tissue (WAT) with unilocular white adipocytes (hematoxylin and eosin stain). Insert shows the ordinary white adipocyte structure characterized by a big central lipid droplet and eccentric (peripheric) nucleus and cytoplasm; (B) Brown adipose tissue (BAT) with multilocular brown adipocytes (hematoxylin and eosin stain). Insert shows the ordinary brown adipocyte structure characterized by abundant mitochondria and several tiny lipid droplets. Between A and B, the insert shows an intermediary "brite" or beige adipocyte. 
Table I. Adipose tissue secretion (Fonseca-Alaniz et al., 2007; Villarroya et al., 2017).

\begin{tabular}{|c|c|}
\hline \multicolumn{2}{|l|}{ White adipose tiss ue secretion } \\
\hline Acylation stimulating protein & Enhances triacylglycerol synthesis in WAT \\
\hline Adiponectin & $\begin{array}{l}\text { Improves insulin sensitivity, is anti-inflammatory, and lessens atherosclerosis } \\
\text { progression }\end{array}$ \\
\hline Adipsin & Activates the alternative complement pathway \\
\hline Angiotensinogen & Involved in regulating blood pressure \\
\hline Apelin & Linked to control of the body's energy stores \\
\hline Apolipoprotein-E + & A protein of the lipoproteins, especially VLDL \\
\hline Cholesterol ester transfer protein $\ddagger$ & Transfers cholesterol esters between lipoproteins \\
\hline Estrogens $\dagger$ & The primary source of estrogen in men and postmenopausal women \\
\hline Glucocorticoids $\dagger$ & Transforms cortisone into cortisol in WAT \\
\hline Hepatocyte growth factor & Stimulates differentiation and development of adipocy tes \\
\hline Insulin-like growth factor-1 & Promotes proliferation and differentiation of adipocy tes \\
\hline Interleukin-6 & Proinflammatory, lipolytic, reduces sensitivity to insulin \\
\hline Leptin & Signals to the central nervous system the energy stocks \\
\hline Lipoprotein lipase $\ddagger$ & Hydrolysis stimulating enzyme in the triacylglycerol of lipoproteins \\
\hline Macrophage migration inhibitor factor & Immunoregulator with paracrine action in WAT \\
\hline Monobutyrin $\uparrow$ & Vasodilator and inducer of vascular neoformation \\
\hline Plasminogen activation inhibitor 1 & Inhibits plasminogen activation blocking fibrinolysis \\
\hline Prostaglandins $\dagger$ & Regulator of various cellular processes, active during inflammation \\
\hline Resistin & Enhances insulin resistance \\
\hline Tissue factor & Starts the coagulation cascade \\
\hline Transforming growth factor-beta & $\begin{array}{l}\text { Proliferation of preadipocytes and differentiation, development and apoptosis of } \\
\text { adipocytes }\end{array}$ \\
\hline Tumor necrosis factor-alpha & Lipolytic enhances energy intake and lessens sensitivity to insulin \\
\hline V ascular endothelial growth factor & Stimulates vascular proliferation in WAT \\
\hline Visfatin & Insulinomimetic mainly produced by visceral fat \\
\hline \multicolumn{2}{|l|}{ Brown adipose tissue secretion } \\
\hline Bone morphogenetic protein $8 b$ & Member of the TGF-beta superfamily \\
\hline Fibroblast growth factor 21 & Cell growth, morphogenesis, tissue repair, tumor growth, and invasion \\
\hline Insulin-like growth factor 1 & Molecular similar in structure to insulin, shows anabolic effects \\
\hline $\begin{array}{l}\text { Insulin-like growth factor-binding } \\
\text { protein } 2\end{array}$ & Transport protein for insulin-like growth factor 1 \\
\hline Interleukin-6 & Proinflammatory, lipolytic, reduces sensitivity to insulin \\
\hline Neuroregulin 4 & Cell signaling through cytosolic tyrosine phosphorylation \\
\hline Slit homolog-2 protein precursor & Cell migration \\
\hline
\end{tabular}

$\dagger$, non-protein molecule; $\$$, protein without hormonal action.

$10 \mu \mathrm{m}$ thickness should be obtained in a cryostat, dried at room temperature for 60 minutes, fixed in $10 \%$ formaldehyde for 10 minutes, and then frozen and again dehydrated for 60 minutes. Afterward, the sections should be placed in $100 \%$ propylene glycol for 3 minutes, stained with a solution of Oil Red pre-heated for 8 minutes at $60{ }^{\circ} \mathrm{C}$, differentiated in $85 \%$ propylene glycol for 3 minutes, washed in tap water for another 3 minutes, and mounted with glycerin (Fig. 2).

In some situations, the white adipocyte may undergo modification and adaptations to work similarly to the brown adipocyte, a process known as "browning," when the white adipocyte is now called "beige" (or brite). For example, the beige adipocyte acquires more mitochondria and starts to express UCP1 (uncoupled protein 1, located in the inner mitochondrial membrane) and expend heat like brown adipocytes (Bargut et al., 2017). Thus, in addition to regulating thermogenesis, BAT improves lipid and carbohydrate homeostasis and contributes to weight loss mediated by rapid heat generation and macronutrient metabolism related to UCP1 function (Bargut et al., 2016; Velickovic et al., 2019).

Thus, the relevant aspects of obesity and adipose tissue should be studied, many of which are experimental research. However, this type of research, which has the potential to unravel mechanisms of action and behavior of adipocytes and fat pads, cannot be carried out initially in humans but must be parameterized in animal research. Therefore, we are 

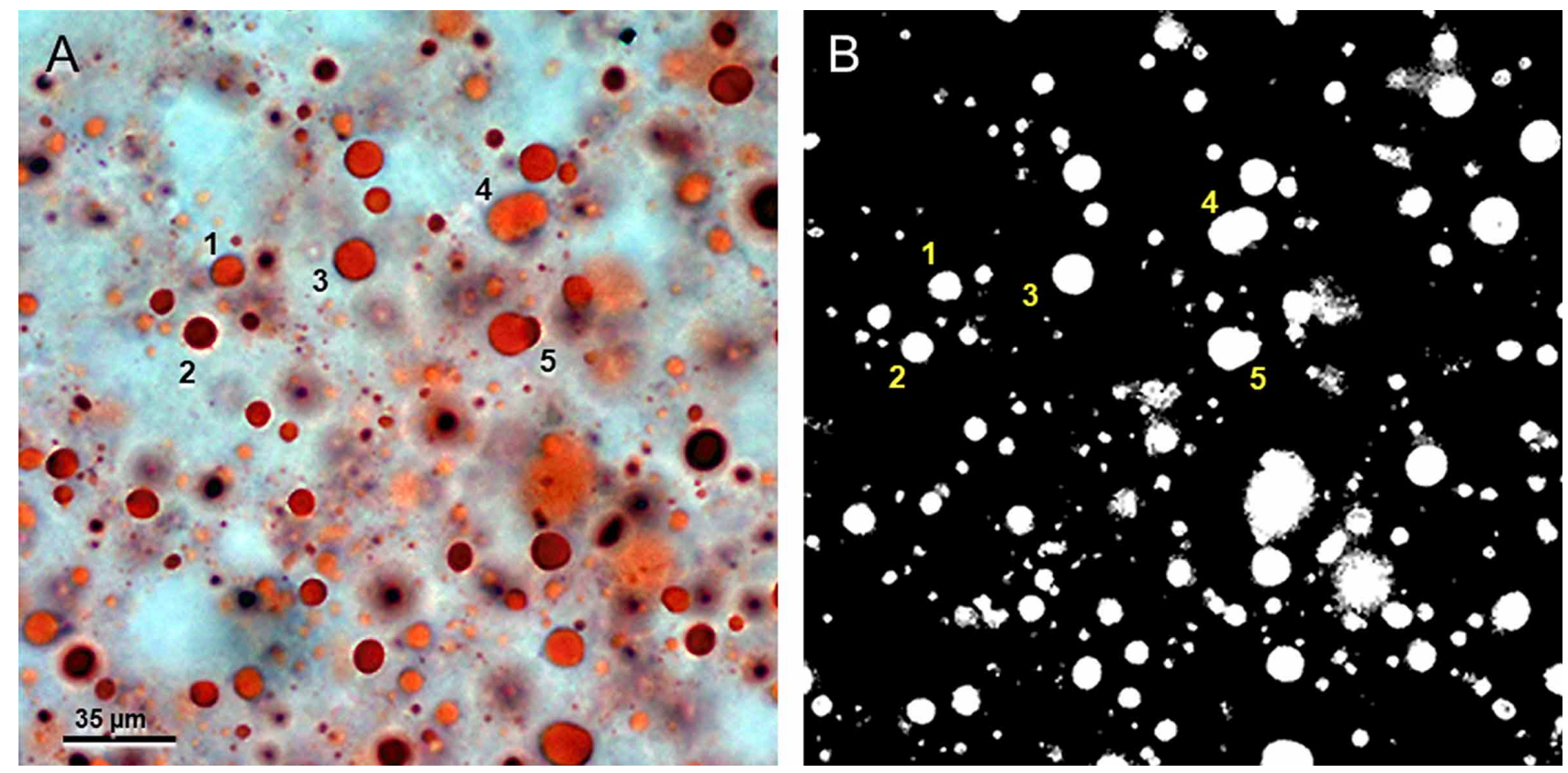

Fig. 2. Oil red preparation. Hepatic steatosis (accumulation of fat drops in hepatocytes, typical of non-alcoholic fatty liver disease). (A) Photomicrographs of frozen sections stained by Oil Red-O showing macro- and microvesicular steatosis. The fat droplets identified by numbers correlate with the segmented image in B; (B) Image analysis of the same microscopic field after image segmentation (transformation to pure black and white image, white assigned to fat vesicles and black assigned to remaining liver tissue).

motivated to present this article with morphological data to guide research on obesity and adipose tissue in the mouse model.

\section{The challenging diagnosis of obesity in rodents}

We have difficulty defining obesity in rodents (Fenton, 1956). Hence, let us start with a parallel with humans. The most straightforward and epidemiologically viable indicator for diagnosing obesity in humans is calculating the body mass index (BMI), the "Quetelet Index" described in 1832. Adolphe Quetelet (1796-1874) was a Belgian scientist who developed a keen attention to probability calculus to study human physical characteristics and social aptitudes (Eknoyan, 2008). The BMI is the body weight (BW, kilograms) to square body height ( $\mathrm{BH}$, meters) ratio, expressed in $\mathrm{kg} / \mathrm{m}^{2}$.

$$
B M I=B W /(B H)^{2}
$$

Several measurements and ratios have been proposed, and are used, to determine how obese a subject is. Currently, the waist circumference and waist-to-hip ratio are recommended (Tutunchi et al., 2020), adjusting target population different biotypes (Western, Asian, male, female, others) (Andreacchi et al., 2021). Also, it should be considered the body adiposity index (BAI = ((hipcircumference)/((height)1.5)-18)), which can be used in the clinical setting to estimate adiposity directly (Bergman et al., 2011).

The World Health Organization agreement on the standardized classification of overweight and obese, based on BMI, allows a comparative analysis of prevalence rates worldwide for the first time (James et al., 2001). The classification generally used for Western adults considers those with BMI $<18.5$ to be underweight. Normal people have BMI between 18.5 and 24.9. Overweight is people with BMI between 25.0 and 29.9. Obese are people with BMI above 30 (Class I, between 30.0 and 34.9; Class II, between 35.0 and 39.9; Class III, above 40.0) (WHO, 2000).

An index was formulated to determine the surface area of rodents, making a parallel between rodents and humans (Lee, 1929). The "Lee index" (generally expressed in percentage) is calculated as the cubic root of BW (in grams) divided by the nasoanal length (NAL, in millimeters) and was proposed to rodents with the same purpose of the human BMI.

$$
\begin{aligned}
& \text { Lee index }=(\sqrt[3]{B W}) /(N A L) \\
& \text { Lee index }=\left(B W^{0.33}\right) /(N A L)
\end{aligned}
$$


However, the Lee index is unappropriated to define obesity in rodents because it is not perfectly correlated with animal body fat, and there are no defined standards for rodent obesity as there are for BMI and human obesity (Stephens, 1980).

Figure 3 shows how the BMI varies in a $1.85 \mathrm{~m}$ tall person and how the Lee index varies in a $120 \mathrm{~mm}$ nasoanal mouse as their BW varies. For example, in humans, the BW increases from $75 \mathrm{~kg}$ to $115 \mathrm{~kg}(+50 \%)$, corresponding to going from BMI 21.9 (normal) to BMI 33.6 (obese, Class I), a BMI change of $53.4 \%$. However, mice growth from 20 $\mathrm{g}$ to $30 \mathrm{~g}(+50 \%)$ parallels a variation of the Lee index from $2.24 \%$ to $2.56 \%$ (in other words, an increase of only $14 \%$ ).

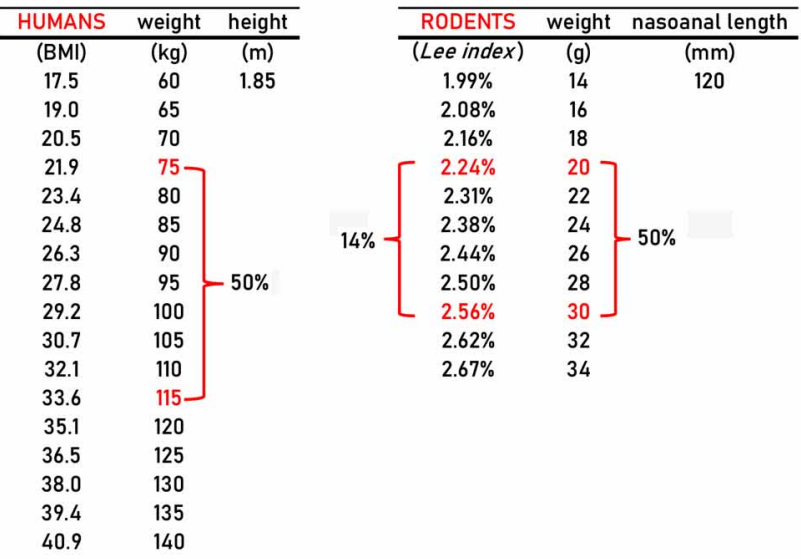

Fig. 3. Obesity indices in humans and rodents. Left side, BMI calculation in a person measuring $1.85 \mathrm{~m}$ varying body weight. Between $75 \mathrm{~kg}$ and $115 \mathrm{~kg}$, BMI went from 21.9 (considered normal) to 33.6 (class I obesity). Right side, Lee index calculation in a mouse with nasoanal length of $120 \mathrm{~mm}$, varying body weight. The growth from $20 \mathrm{~g}$ to $30 \mathrm{~g}$ changes the Lee index only from $2.24 \%$ to $2.56 \%$, indicating that it is not a good marker to assess obesity in this animal.

The composition of animal carcass study might be used to determine fat content and weight gain (the carcass should be defatted in ether and measured). The carcass analysis technique determines the water content by drying the whole carcass. The dried carcass is then ground to powder, and the fat content is determined using an ether extraction method. Also, the protein content might be determined in fat extracted material. See details in the reference (Leshner et al., 1972). However, it is a laborious method, especially when we should compare several animals in each sample. Nowadays, fat analysis in rodents might be replaced with an advantage by DEXA (small animal dualenergy $\mathrm{x}$-ray densitometry) (https:// www.microphotonics.com/products/inalyzer-dexa-systems/ inalyzer-dexa-systems/).
In a population of regular and obese mice, the weight to length ratio estimates body fat more reliable than the Lee Index (because the Lee index did not correlate well enough with body fat to be used as a method of obesity estimation), as well as the carcass analysis. Therefore, the proportional weight of the gonadal fat pad is now recommended as a simple, consistent estimate of body fat in normal or obese mice (Rogers \& Webb, 1980). Moreover, a suitable but not always accessible alternative for analyzing fat distribution in rodents is DEXA.

\section{Rodent fat pads}

Different fatty pads in rodents (as in humans) have distinct structural and functional characteristics. Fat pads are the places where adipocytes preferentially group and fat accumulates in rodents. Fat accumulation might occur by increasing the number of adipocytes (hyperplasia) and increasing the size of adipocytes (hypertrophy). The subcutaneous adipose tissue is the largest and least harmful adipose depot to store excess lipids. However, it has a limited ability to expand and recruit new cells. When the subcutaneous adipose cells become expanded (hypertrophic obesity), this leads to dysregulated and dysfunctional subcutaneous adipose tissue and ectopic fat accumulation in many depots (Gustafson \& Smith, 2015). The visceral fat has a more significant potential to produce hormones and cytokines, including inflammatory ones, while subcutaneous fat can undergo the most intense browning process. Fig. 4 . illustrates fat distribution in mice.

I. The inguinal fat pad is the subcutaneous fat (located between the lower part of the rib cage and the mid-thigh). The subcutaneous fat is where usually browning occurs when stimulated.

II. The intra-abdominal or visceral fat pad is composed of various compartments:

a) the fat around de branches of the superior and inferior mesenteric arteries (situated between the leaflets of the mesentery). Here, the evaluation of cytokines and proinflammatory markers is suitable;

b) the retroperitoneal fat (connected to the posterior abdominal wall near the kidneys). Here, fat remains even after weight loss;

c) the genital (gonadal) fat (located in the lower part of the abdomen, connected to the epididymis in males or the ovaries and oviducts in females). This fat pad is suitable for cytokines and proinflammatory markers evaluation.

III. The interscapular and mediastinal fats are rich in BAT's multilocular adipocytes.

The adiposity index is another possibility to evaluate 


\section{Mice adipose tissue distribution}

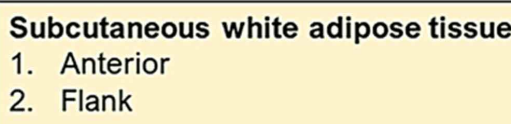

2. Flank

\section{Visceral white adipose tissue}

3. Mesenteric

4. Retroperitoneal

5. Perirenal

6. Perigonadal

\section{Brown adipose tissue}

7. Interscapular

8. Mediastinal (not shown)
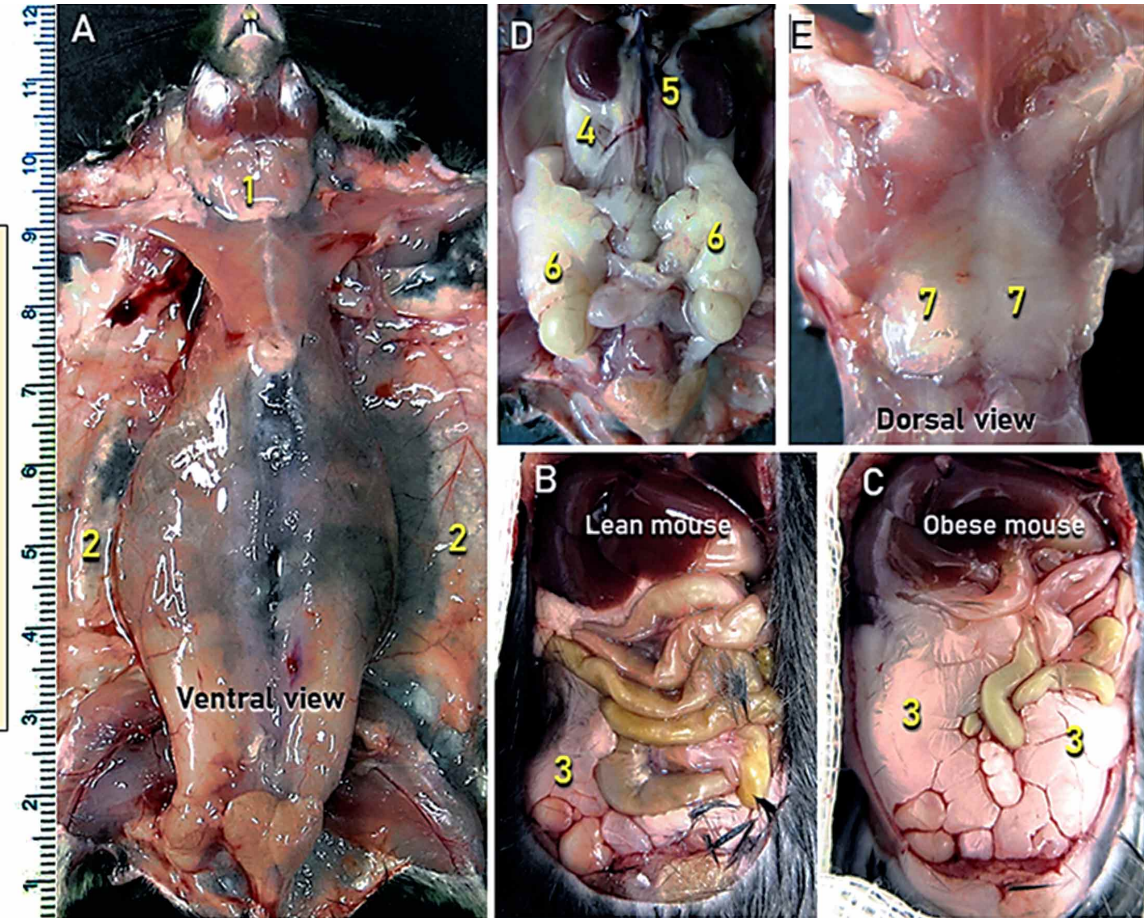

Fig. 4. Mice adipose tissue distribution. In the dissected images, the various fat pads named in the left frame are indicated. (A) ventral view showing the anterior subcutaneous tissue (1) and the flank (2); (B) and (C) ventral view of the open abdominal cavity in a thin mouse (B) and an obese mouse (C) indicating mesenteric fat (3); (D) dissection of the posterior portion of the abdomen indicating the retroperitoneal (4), perirenal (5) and perigonadal (6) pads; (E) animal's dorsal view of the interscapular fat (7, brown adipose tissue).

body fat in rodents. For example, it might be determined as the ratio between the sum of the fat masses divided by the total BW, presented as a percentage (Pawlak et al., 2004).

The size of white adipocytes varies with obesity. Frequently the white adipocyte diameter is measured to characterize its size variation. However, the white adipocyte diameter analysis is only valid to interpret the variations due to obesity if the section cuts the adipocyte in the equatorial plane because adipocytes are nearly spheric (sometimes adipocytes cut in the polar plane appear with a smaller diameter than the actual diameter). As we cannot be sure of this, the averaged adipocyte cross-sectional area might be estimated using the probabilistic statistics of stereology (Mandarim-de-Lacerda \& del Sol, 2017): the ratio between the volume density of adipocytes $\left(\mathrm{V}_{\mathrm{v}}\right.$ [adipocyte] $)$ and twice the numerical density of adipocyte per area or $\mathrm{Q}_{\triangle}$ [adipocyte] (Borges et al., 2020).

In brown adipocytes, the estimation of $\mathrm{V}_{\mathrm{v}}$ [fat droplets] might be helpful as $\mathrm{V}_{\mathrm{v}}$ [fat droplets] rise indicates BAT increased multiloculation (Marinho et al., 2020). In addition, the browning intensity evaluation in adipose tissue might be evaluated by estimating the $\mathrm{Q}_{\mathrm{A}}$ [nuclei, WAT], considering that WAT usually shows fewer nuclei per area than BAT.

$$
\begin{gathered}
V_{V}[\text { adipocyte }]=P_{p}[\text { adipocyte }] / P_{T} \\
Q_{A}[\text { adipocyte }]=N[\text { adipocyte }] / A_{T} \\
\bar{a}[\text { adipocyte }]=V_{V}[\text { adipocyte }] / 2 Q_{A}[\text { dipocyte }]
\end{gathered}
$$

Abbreviations: $\bar{a}$ [adipocyte] is the cross-sectional area of adipocytes; $\mathrm{A}_{\mathrm{T}}$ is the test area; $\mathrm{N}$ [adipocyte] is the number of adipocytes; $\mathrm{P}_{\mathrm{P}}$ [adipocyte] is the point counting; $\mathrm{P}_{\mathrm{T}}$ is the total number of test-point in the frame; $\mathrm{Q}_{A}$ [adipocyte] is the numerical density per area of adipocytes; $\mathrm{V}_{\mathrm{V}}$ [adipocyte] is the volume density of adipocytes (Mandarim-de-Lacerda, 2003).

\section{Final remarks}

Rodents, particularly mice, can contribute to the study of obesity with translation to human studies. First, however, the scientist needs to know and consider the particularities of the animals, such as the various types of fat pads, their location, and suitability for the study proposed. For example, the visceral fat fits hormone and adipokine secretion investigation, while the subcutaneous fat might be used to 
examine browning. Furthermore, heat production and thermogenesis are better analyzed in brown fat.

Moreover, there are different strains of rodents. For example, the Swiss (white) mouse is less susceptible to fattening by diet than the C57BL/6 mouse strain (a wildtype control for all possibilities of gene silencing).

\section{ACKNOWLEDGMENTS}

We are grateful to Mariana Catta-Preta for Oil red preparation (Fig. 2), Fabiane Martins, Thatiany Marinho, and Patricia Paiva for mice dissections (Fig. 3). We also thanks the support given by Conselho Nacional de Desenvolvimento Científico e Tecnológico (Brazil) (CNPq, Grant No 302.920/2016-1 and 40.60.81/2018-2 to CML and 305.865/2017-0 to MBA), and Fundação Carlos Chagas Filho de Amparo à Pesquisa do Estado do Rio de Janeiro (Faperj, Grant No E-26/202.935/2017 and E-26/010.100947/ 2018 to CML and E-26/202.795/2017 to MBA).

MANDARIM-DE-LACERDA, C. A.; DEL SOL, M.; VÁSQUEZ, B. \& AGUILA, B. M. Ratones como modelo animal para el estudio del tejido adiposo y la obesidad. Int. J. Morphol., 39(6):1521-1528, 2021.

RESUMEN: El estudio del tejido adiposo ha ganado una importancia creciente en el área biomédica por sus implicaciones para la salud y la obesidad. La obesidad es una situación de gran preocupación, principalmente, en el mundo occidental debido a su alta prevalencia y morbilidad. Los estudios experimentales sobre la obesidad a menudo necesitan un modelo en el que sea posible realizar experimentos, pruebas de drogas y otros procedimientos terapéuticos, que normalmente no son posibles en humanos. Aunque se utilizan varios animales para estudios de obesidad, los roedores son, con mucho, los animales más utilizados y, entre los roedores, los ratones están especialmente indicados para esta investigación. Esta mini revisión presenta la desafiante clasificación de la obesidad en roedores, en paralelo con la obesidad humana, definiendo y clasificando qué es un ratón obeso. El texto diferencia entre tejido adiposo blanco (WAT, destinado a la secreción endocrina y lipogénesis) y tejido adiposo marrón (BAT, destinado a la termogénesis) y describe el proceso de pardeamiento de los adipocitos blancos en una adaptación para aumentar la termogénesis. El texto también describe los diversos tipos de grasa corporal en ratones con sus diferencias e indicaciones para la investigación y enseña cómo reconocer y diseccionar estas grasas. Al final de esta lectura introductoria, se espera que el joven investigador haya adquirido los conocimientos suficientes para iniciar un proyecto de investigación experimental sobre la obesidad.

PALABRAS CLAVE: Obesidad; Tejido adiposo blanco; Tejido adiposo marrón; Almohadillas de grasa; Ratones.

\section{REFERENCES}

Aguila, M. B.; Ornellas, F. \& Mandarim-de-Lacerda, C. A. Nutritional research and fetal programming: parental nutrition influences the structure and function of the organs. Int. J. Morphol., 39(1):327-34, 2021. (doi: 10.4067/s0717-95022021000100327).

Andreacchi, A. T.; Griffith, L. E.; Guindon, G. E.; Mayhew, A.; Bassim, C.; Pigeyre, M.; Stranges, S. \& Anderson, L. N. Body mass index, waist circumference, waist-to-hip ratio, and body fat in relation to health care use in the Canadian Longitudinal Study on Aging. Int. J. Obes. (Lond), 45:666-76, 2021. (doi: 10.1038/s41366-020-00731-z).

Armitage, J. A.; Poston, L. \& Taylor, P. D. Developmental origins of obesity and the metabolic syndrome: the role of maternal obesity. Front. Horm. Res., 36:73-84, 2008 (doi: 10.1159/0000115355).

Bargut, T. C.; Aguila, M. B. \& Mandarim-de-Lacerda, C. A. Brown adipose tissue: Updates in cellular and molecular biology. Tissue Cell, 48(5):452-60, 2016 (doi: 10.1016/j.tice.2016.08.001).

Bargut, T. C.; Souza-Mello, V.; Aguila, M. B. \& Mandarim-de-Lacerda, C.A. Browning of white adipose tissue: lessons from experimental models. Horm. Mol. Biol. Clin. Investig., 31, 2017 (doi: 10.1515/ hmbci-2016-0051).

Bergman, R. N.; Stefanovski, D.; Buchanan, T. A.; Sumner, A. E.; Reynolds, J. C.; Sebring, N. G.; Xiang, A. H. \& Watanabe, R. M. A better index of body adiposity. Obesity (Silver Spring), 19(5):10839, 2011. (doi: 10.1038/oby.2011.38).

Bluher, M. Obesity: global epidemiology and pathogenesis. Nat. Rev. Endocrinol., 15(5):288-98, 2019. (doi: 10.1038/s41574-019-01768).

Borges, C. C.; Bringhenti, I.; Aguila, M. B. \& Mandarim-de-Lacerda, C. A. Vitamin D restriction enhances periovarian adipose tissue inflammation in a model of menopause. Climacteric, 23(1):99-104, 2020. (doi: 10.1080/13697137.2019.1597841).

Catta-Preta, M.; Martins, M.A.; Cunha Brunini, T. M.; Mendes-Ribeiro, A. C.; Mandarim-de-Lacerda, C. A. \& Aguila, M.B. Modulation of cytokines, resistin, and distribution of adipose tissue in C57BL/6 mice by different high-fat diets. Nutrition, 28(2):212-9, 2012. (doi: 10.1016/ j.nut.2011.05.011).

Eknoyan, G. Adolphe Quetelet (1796-1874)-the average man and indices of obesity. Nephrol. Dial Transplant., 23(1):47-51, 2008. (doi: 10.1093/ndt/gfm517).

Fenton, P.F. Growth and fat deposition in the mouse; a definition of obesity. Am. J. Physiol., 184(1): 52-4, 1956. (doi: 10.1152/ ajplegacy.1955.184.1.52).

Fonseca-Alaniz, M. H.; Takada, J.; Alonso-Vale, M. I. \& Lima, F. B. Adipose tissue as an endocrine organ: from theory to practice. $J$. Pediatr. (Rio J), 83(5 Suppl):S192-203, 2007 (doi: doi:10.2223/ JPED.1709).

Fraulob, J. C.; Ogg-Diamantino, R.; Santos, C. F.; Aguila, M. B. \& Mandarim-de-Lacerda, C. A. A mouse model of metabolic syndrome: insulin resistance, fatty liver and non-alcoholic fatty pancreas disease (NAFPD) in C57BL/6 mice fed a high fat diet. J.Clin. Biochem. Nutr., 46(3):212-23, 2010. (doi: 10.3164/jcbn.09-83).

Gesta, S.; Tseng, Y.H.\& Kahn, C. R. Developmental origin of fat: tracking obesity to its source. Cell, 131(2):242-56, 2007 (doi: 10.1016/ j.cell.2007.10.004).

Gustafson, B. \& Smith, U. Regulation of white adipogenesis and its relation to ectopic fat accumulation and cardiovascular risk. Atherosclerosis, 241(1):27-35, 2015. (doi: 10.1016/j.atherosclerosis.2015.04.812).

James, P. T.; Leach, R.; Kalamara, E. \& Shayeghi, M. The worldwide obesity epidemic. Obes. Res., 9 Suppl 4:228S-33S, 2001. (doi: 10.1038/oby.2001.123).

Langin, D. Recruitment of brown fat and conversion of white into brown adipocytes: strategies to fight the metabolic complications of obesity? Biochim Biophys Acta, 1801(3):372-6, 2010. (doi: 10.1016/ j.bbalip.2009.09.008). 
Lee, M. O. Determination of the surface area of the white rat with its application to the expression of metabolic results. Am. J. Physiol., 89: 24-33, 1929. (doi: 10.1152/ajplegacy.1929.89.1.24).

Leshner, A. I.; Litwin, V. A. \& Squibb, R. L. A simple method for carcass analysis. Physiol. Behav., 9(2):281-2, 1972. (doi: 10.1016/00319384(72)90251-x).

Lutz, T. A. \& Woods, S. C. Overview of animal models of obesity. Curr. Protoc. Pharmacol., 5(Unit 5.61):1-18, 2012 (doi: 10.1002/ 0471141755.ph0561s58).

Mandarim-de-Lacerda, C.A. Stereological tools in biomedical research. An . Acad. Bras. Cienc., 75(4):469-86, 2003. (doi: 10.1590/S000137652003000400006).

Mandarim-de-Lacerda, C. A. \& del Sol, M. Tips for Studies with Quantitative Morphology (Morphometry and Stereology). Int.J.Morphol., 35(4):148294, 2017. (doi: 10.4067/s0717-95022017000401482).

Marinho, T. S.; Ornellas, F.; Aguila, M. B. \& Mandarim-de-Lacerda, C. A. Browning of the subcutaneous adipocytes in diet-induced obese mouse submitted to intermittent fasting. Mol.Cell Endocrinol., 513:110872, 2020 (doi: 10.1016/j.mce.2020.110872).

Martins, F. F.; Souza-Mello, V.; Carvalho, J. J.; Aguila, M. B. \& Mandarimde-Lacerda, C. A. Liver structural injury in leptin-deficient (ob/ob) mice: lipogenesis, fibrogenesis, inflammation, and apoptosis. Int. J. Morphol., 39(3):732-8, 2021. (doi: 10.4067/S0717-95022021000300732).

Micro Photonics Inc: InAlyzer DEXA Systems, 2021. https:// www.microphotonics.com/products/inalyzer-dexa-systems/inalyzer-dexasystems/.

Ornellas, F.; Souza-Mello, V.; Mandarim-de-Lacerda, C. A. \& Aguila, M. B. Combined parental obesity augments single-parent obesity effects on hypothalamus inflammation, leptin signaling (JAK/STAT), hyperphagia, and obesity in the adult mice offspring. Physiol. Behav., 153:47-55, 2016. (doi: 10.1016/j.physbeh.2015.10.019).

Pawlak, D. B.; Kushner, J. A. \& Ludwig, D. S. Effects of dietary glycaemic index on adiposity, glucose homoeostasis, and plasma lipids in animals. Lancet, 364(9436):778-85, 2004. (doi: 10.1016/S0140-6736(04)169377).

Rogers, P. \& Webb, G.P. Estimation of body fat in normal and obese mice. $\mathrm{Br}$. J. Nutr., 43(1):83-6, 1980. (doi: 10.1079/bjn19800066).

Spezani, R.; Silva, R. R.; Martins, F. F.; Marinho, T. S.; Aguila, M. B. \& Mandarim-de-Lacerda, C. A. Intermittent fasting, adipokines, insulin sensitivity, and hypothalamic neuropeptides in a dietary overload with high-fat or high-fructose diet in mice. J.Nutr. Biochem., 83:108419, 2020 (doi: 10.1016/j.jnutbio.2020.108419).

Stephens, D. N. Does the Lee obesity index measure general obesity? Physiology \& Behavior, 25(2):313-5, 1980 (doi: 10.1016/00319384(80)90222-X).

Tutunchi, H.; Ebrahimi-Mameghani, M.; Ostadrahimi, A. \& AsghariJafarabadi, M. What are the optimal cut-off points of anthropometric indices for prediction of overweight and obesity? Predictive validity of waist circumference, waist-to-hip and waist-to-height ratios. Health Promot.Perspect., 10(2):142-7, 2020. (doi: 10.34172/hpp.2020.23).

Velickovic, K.; Wayne, D.; Leija, H. A. L.; Bloor, I.; Morris, D. E.; Law, J.; Budge, H.; Sacks, H.; Symonds, M. E. \& Sottile, V. Caffeine exposure induces browning features in adipose tissue in vitro and in vivo. Sci Rep, 9(1):9104, 2019. (doi: 10.1038/s41598-019-45540-1).

Villarroya, F.; Cereijo, R.; Villarroya, J. \& Giralt, M. Brown adipose tissue as a secretory organ. Nat.Rev.Endocrinol., 13(1):26-35,2017. (doi: 10.1038/ nrendo.2016.136)

Villarroya, J.; Cereijo, R.; Gavalda-Navarro, A.; Peyrou, M.; Giralt, M. \& Villarroya, F. New insights into the secretory functions of brown adipose tissue. J. Endocrinol., 243(2):R19-R27, 2019. (doi: 10.1530/JOE-190295).

World Health Organization (WHO). Obesity: preventing and managing the global epidemic. Report of a WHO consultation. WHO technical report series, 894:1-253, 2000. (https://apps.who.int/iris/handle/10665/42330).

World Health Organization (WHO). Obesity and overweight. 2021. https:// www.who.int/news-room/fact-sheets/detail/obesity-and-overweight
Corresponding author:

Carlos Alberto Mandarim-de-Lacerda

Laboratório de Morfometria

Metabolismo e Doença Cardiovascular

Centro Biomédico

Instituto de Biologia

Universidade do Estado do Rio

Rio de janeiro

BRAZIL

E-mail: mandarim@uerj.br

Orcid: 0000-0003-4134-7978

Mariano del Sol

E-mail: mariano.delsol@ufrontera.cl

Orcid: 0000-0003-3686-6757

Bélgica Vásquez

E-mail: bvasquezp@academicos.uta.cl

Orcid: 0000-0002-4106-3548

Marcia Barbosa Aguila

E-mail: mbaguila@uerj.br

Orcid: 0000-0003-3994-4589

Received: 17-08-2021

Accepted: 21-09-2021 